\title{
THE INFLUENCE OF TEACHING ENGLISH VOCABULARY USING VCD LEARNING TO THE KINDERGARTEN LEVEL IN SMART AND FUN COMMUNICATIVE ENGLISH COURSE SAMARINDA
}

\author{
Ikhwanul Ahsan Faryabi Muja \\ Akademi Bahasa Asing COLORADO Samarinda, Indonesia \\ ikhwan_muja@yahoo.com
}

\begin{abstract}
The researcher used VCD Learning to help kindergarten level students Smart and Fun Communicative English Program Samarinda on learning English vocabulary. The contents were relevant to the vocabulary for students in kindergarten level of Smart and Fun Samarinda.This study was aimed finding whether there was significance difference between experimental and control groups and whether there was significant difference between post experimental and control groups. It is a kind of experimental research. This study's design was two group-pretest-treatment-posttest design. The population of this study was 60 students. The researcher took 40 students from two classes as the sample of this study. Then, took other 20 students as try out test respondents. The test was tried out to 20 respondents consisted of 30 items. After being analyzed, its reliability coefficient was 0.462 . The experimental group's mean score on the post-test was 80.17 while on control group was 70.67. After analyzing the two mean scores by using the program of SPSS 16.0, it was found that the difference significance value between the two mean scores $\mathrm{t}$ - computed 4.068 was higher than $\mathrm{t}$ - table 2.093 with the level of significant $5 \%$. The computation showed that the two groups' mean scores of significantly differed. Thus, the alternative hypothesis (Ha) is accepted and the Null Hypothesis (Ho) is rejected. It could be concluded that there was significant difference of English vocabulary achievement among students of kindergarten level of Smart and Fun by using VCD Learning.
\end{abstract}

Keywords: Teaching Vocabulary, VCD Learning, Kindergarten Level Students.

\section{INTRODUCTION}

Early childhood education is successful becomes the parents' trend in education field nowadays. Non-formal education is also becomes one of the parents' choices in helping their children improving their achievement in learning. The parents think that the learning activities which their children have at school have not been enough. It is because the learning activities which schools usually use are the conventional one where only the teachers are active in the class.

Many of the parents want their children are able to master the lessons at school especially English. It is because English is one of the lessons which have to be learnt in a very young age at school now. In order to learn language especially English which is a 
foreign language for Indonesian students, vocabulary is the most important thing that should be aware. Because by mastering sufficient vocabularies it will help them learning English more easily. One of the problems which usually occurs when the children learn English vocabulary is they seem really easy to forget about the vocabularies which have been taught by the teachers. They find it is boring to learn vocabularies in the class because the teachers only use the teaching technique which may be lack of the instructional aid of learning. This may because the students' memory in memorizing the vocabularies becomes weak.

In learning a foreign language, vocabulary plays an important role. It is one element that links the four skills of speaking, listening, reading and writing all together. In order to communicate well in a foreign language, students should acquire an adequate number of words and should know how to use them accurately.

As we know that vocabulary has an important role in learning language. Even though students realize the importance of vocabulary when learning language, most Indonesian students learn vocabulary passively due to several factors. Huyen \& Nga (2003) mentioned there are several factors related to the students' vocabulary learning:

a. Students usually only acquire new vocabulary through new words in their textbooks or when given by teachers during classroom lessons.

b. Students only think of vocabulary learning as knowing the primary meaning of new words. Therefore, they ignore all other functions of the words.

c. They consider the teacher's explanation for meaning or definition, pronunciation, spelling and grammatical functions boring.

d. Many learners do not want to take risks in applying what they have learnt. Students may recognize a word in a written or spoken form and think that they already "know the word", but they may not be able to use that word properly in different contexts or pronounce it correctly.

Teaching English to children is different to teaching adults. We need to teach the children harder and with distinct way as we usually do to the adults. To help students learning more easily, especially vocabulary lessons and make it more enjoyable we need to use interesting activities. Consequently, the teacher is demanded to be creative and be good model in teaching English for their students. As the basic components of the four language skills (listening, reading, writing and speaking) vocabulary has to be mastered by learners. Without having adequate vocabulary we will get difficulty in learning English. For kids,

Script Journal Volume 1, Issue 2, October 2016 || P-ISSN 2477-1880 || E-ISSN 2502-6623 http://jurnal.fkip-uwgm.ac.id/index.php/Script 
vocabulary is the first step to learn English, because without knowing a lot of vocabulary in English the children will get difficulties in mastering English.

Through this study the researcher wanted to examine a technique which is hoped can be a good method for teaching vocabulary to the students in kindergarten level. Here, the researcher tried to present VCD Learning as a teaching English medium to the students in kindergarten level. Teaching English using VCD Learning can be considered as one of the appropriate methods.

In teaching vocabulary to the Kindergarten level students, the teacher had be more creative and able to keep the students away from getting bored. The teacher needs some ways or aids. In order to keep the students away from getting bored in learning vocabulary, the teacher should use an appropriate instructional media. This media should gain the students' interest in learning new vocabulary. Media such as cartoon, VCD, tape recorder, overhead projector, radio, television, computer, Interactive White Board (IWB) and etc. play important role in teaching vocabulary. They are very useful for the teacher to achieve the instructional goals and the objectives of learning, besides as a tool to command students in teaching learning process.

Yang \& Fang (2008) said that "multimedia teaching stresses the role of the students, and enhances the importance of "interaction" between teachers and students. Its major feature is to train and improve students' ability to listen, to speak, and to develop their communicative competence". The use of CVD Learning as media can be a choice for the teacher in teaching vocabulary in which the students will be given a chance to study vocabulary in different way which is hoped that they will be motivated and confidence in learning vocabulary.

Brophy \& Good (1986) imply that the toys and manipulative equipment. Although available for the children should be selected with care, because in a very real sense these items represent the basic curriculum of the preschool. The ideal of kinds of toys and equipment to purchase are those that; 1.Are interesting and enjoyable to the children. 2. Are safe (no glass, sharp edges, lead-based paint, pieces small enough to invite swallowing and choking, or other potential safety hazards). 3. Are sturdy and durable. 4. Are flexible enough to be used for a variety of purposes, thus inviting repeated used and fostering creativity in play. 5. Invite active manipulation and provide for automatic self-correction, so that the

Script Journal Volume 1, Issue 2, October 2016 || P-ISSN 2477-1880 || E-ISSN 2502-6623 http://jurnal.fkip-uwgm.ac.id/index.php/Script 
children learn as they play. 6. Are useful in teaching recognition and discrimination of size, shape, color, number, texture, and other basic concepts or sensory aspects of objects.

As Harmer (2007) says that video is richer than audio tape. Speakers can be seen. Their body movements give clues as to meaning, so do the clothes they wear, their location etc. Background information can be filled in visually. Besides, many teachers use video because it brings an extra dimension to the class and can be most enjoyable.

For the reasons above, the researcher wanted to try to use Video Compact Disc Learning or VCD Learning as a medium for teaching vocabulary to the students in Kindergarten level. The researcher hoped that it would be an effective and interesting medium in teaching vocabulary to the students, so that they can enjoy and interested in learning vocabulary.

\section{METHODOLOGY}

\section{Research Design}

The design which was used in this study is quasi-experimental. The researcher attempted to determine the influence of using VCD Learning on students' vocabulary acquisition. The impact of using VCD Learning on the students' vocabulary retention was based on quantitative analysis of the results of the pre-test and the post tests. According to Creswell (1994) experiment is highly controlled method. Experiment gives the researcher valuable data for judging and comparing the changes in the scores between the experimental group and the control group in the pretests and posttests. The comparison of the results of the pretests and posttests between two groups and each group helps the researcher clarify how the treatment has influenced the subjects' vocabulary scores. The independent variable focused upon was the strategy of using VCD Learning to teach new vocabulary. The dependent variable was the students' vocabulary acquisition.

\section{Population, Sample and Setting}

The population in this research comprised 60 students in three classes of Smart and Fun English course of Kindergarten Classes. Two classes of Kindergarten level were selected for this research. These two classes were then randomly selected as experimental group and control group. The experimental group (Banana class) was taught by using VCD Learning as the treatment, whereas the control group (Grape Class) received material without using VCD Learning. In the experimental group, there were 20 students. The control group was

Script Journal Volume 1, Issue 2, October 2016 || P-ISSN 2477-1880 || E-ISSN 2502-6623 http://jurnal.fkip-uwgm.ac.id/index.php/Script 
composed of 20 students as well. The age of the participants in both the experimental group and the control group were around five to seven.

The researcher conducted Pre-test - Treatment - Post-test stages for both groups. In the pre-test, the students were asked to demonstrate knowledge of all the vocabulary focused upon the target vocabulary which is targeted in the VCD Learning. In this study the researcher used a performance test. The teacher said some words one by one and asked the students to points the pictures that the teacher meant. Students had to point the picture to its suitable word. It was done to all of students one by one. The tryout test was made by the researcher himself. The resource of test was taken from VCD Learning Ayo Belajar Bahasa Inggris Vol 4 \& Vol 5" created by PT ELEX MEDIA KOMPUTINDO. In the treatment for experimental group, it was taught by learning new vocabulary from VCD Learning. The overall time to teach was about 45 minutes. 5 minutes was used to explain the material and then 20 minutes was taken for playing VCD Learning. Nevertheless the treatment for controlled group was teaching by using non VCD Learning technique or Classical/Conventional method. This meant that the students were given a set of pre - test before the treatment. The overall time to teach was 70 minutes. After having finished the treatment, the researcher conducted post - test to the students. The time taken for this post test was 70 minutes. Through the test the researcher would like to find out the result from the scores by comparing the two groups in order to see the significant difference by using paired sample $t$-test in the program of SPSS 16.0.

The validity of the test material in this study that was checked was only the content validity. Content validity in this study refers to whether a measure covers the material that it claims that it fairly and comprehensively covers the domain or items that it purports to cover, and in this research all of the items that were used as the test material were suitable and the same as the materials that were in VCD Learning Ayo Belajar Bahasa Inggris Vol 4 \& Vol 5" created by PT ELEX MEDIA KOMPUTINDO.

The researcher used Split - Half method to measure the reliability, which the items of the single test will be divided into:

- Odd number as group $\mathrm{x}$

- Even number as group y

Script Journal Volume 1, Issue 2, October 2016 || P-ISSN 2477-1880 || E-ISSN 2502-6623 http://jurnal.fkip-uwgm.ac.id/index.php/Script 
After having the coefficient of correlation of the whole test, then it was compared with r-table Product Moment. If the result of $\mathrm{r}$ computation is higher than r-table, it means that the test is reliable.

\section{Data Collection Techniques}

In order to collect the data for this study, two tests were given. The purpose of each test follows:

1. Pre-test: To establish a baseline for determining vocabulary growth throughout the instructional process. The students were asked to demonstrate knowledge of all the vocabulary focused upon the target vocabulary which is targeted in the VCD Learning.

2. Post-test: To allow the students showing their vocabulary acquisition and retention throughout the process.

Each test was described in more detail in the following sections.

\section{Data Collection Technique 1}

The first data collection technique was the pre-test which was administered to assess understanding of the key vocabulary words through a performance test using the selection of vocabulary words addressed during the study. The pre-tests was given prior to any instruction on the target vocabulary words. These teacher-created exams were used to establish a baseline to ascertain growth over the course of the instruction. The performance pretest was scored simply by awarding a point for every correct answer and determining an overall percentage.

\section{Data Collection Technique 2}

The post-test was a repetition of the pre-test procedure. The post-test was given one week after the final instructional period concluded. The results from this test were used to compare the result of the post-test with the pre-test results in order to determine vocabulary acquisition growth over the course of the instructional period. This test also was used to determine if and to what extent retention of the targeted words have taken place. All attempts were made to use pictures on the post-test that was an obvious example of the key vocabulary term to native speakers.

There are the procedures that the researcher carried out to collect the data needed:

1. Conducting the try out test to the 20 students of Kindergarten level in Smart and Fun English Course Samarinda.

Script Journal Volume 1, Issue 2, October 2016 || P-ISSN 2477-1880 || E-ISSN 2502-6623 http://jurnal.fkip-uwgm.ac.id/index.php/Script 
2. Finding out the best way or procedure in giving instructions to the students when giving the try out to the try out students for real test (pre-test and post-test).

3. Dividing the sample members into two groups, an experimental group (Group A) and a control group (Group B) by using simple random sampling method.

4. Conducting the pre-test for both experimental and control group.

5. Giving the treatment of using VCD Learning to experimental group, while control group is taught without using VCD Learning.

6. Giving the post - test to both groups to collect the data.

7. Find out the result.

8. Compare the two groups in order to see the significant difference by using paired sample $t$ - test in the program of SPSS 16.0.

\section{Data Analysis Techniques}

In accordance with the purposes of this research, it can be seen the comparison between the result of experimental group and control group. To investigate whether the hypothesis are accepted or rejected the researcher used t-test formula. In this study, the researcher used paired sample t-test in the program of SPSS 16.0.

Order to determine whether hypothesis of the research was accepted or rejected, the researcher used the formula as follows:

If tc $\geq \mathrm{t}$-table or $\mathrm{t}$-table $\leq \mathrm{tc}$, Ho is rejected and Ha is accepted.

If tc $<\mathrm{t}$-table or t-table $>\mathrm{tc}$, Ho is accepted and $\mathrm{Ha}$ is rejected.

Where:

tc : Computed $t$

Ho : The Null hypothesis (the hypothesis of two variables that there is no difference between them)

Ha : The Alternative Hypothesis (the hypothesis of two variables that has significant difference between them)

\section{FINDING}

Findings of this study consist of the influence of teaching English using VCD Learning on Kindergarten level students' vocabulary acquisition In Smart and Fun English Course Samarinda.

Script Journal Volume 1, Issue 2, October 2016 || P-ISSN 2477-1880 || E-ISSN 2502-6623 http://jurnal.fkip-uwgm.ac.id/index.php/Script 


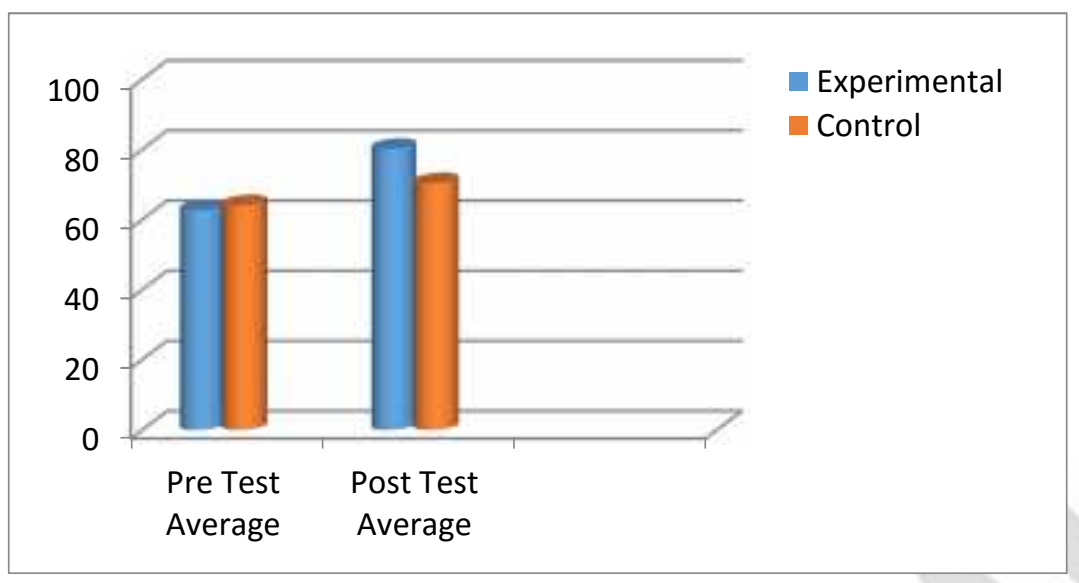

Figure 4.1 Pre-Post Average Score Experimental and Control Groups

After giving the stages, the researcher found the average scores from both pre and post- test of Experimental and Control Group. For Pre Test and Post Test of Experimental was 62.7 and 80.2, for Pre Test and Post Test Control Group was 64.1 and 70.4.

\begin{tabular}{|ll|l|l|l|l|}
\hline & & & & Std. Error \\
Mean & $\mathrm{N}$ & Std. Deviation & Mean \\
\hline Pair 1 & $\begin{array}{l}\text { Experimental Group } \\
\text { Control Group }\end{array}$ & 80.1667 & 20 & 10.31548 & 2.30661 \\
& 70.3500 & 20 & 12.95235 & 2.89623 \\
\hline
\end{tabular}

Table 1. Paired Samples Statistics

\begin{tabular}{|lll|l|l|l|}
\hline & & N & Correlation & Sig. \\
\hline Pair 1 & $\begin{array}{l}\text { Experimental Group \& } \\
\text { Control Group }\end{array}$ & 20 & .606 & .005 \\
\hline
\end{tabular}

Table. 2 Paired Samples Correlations

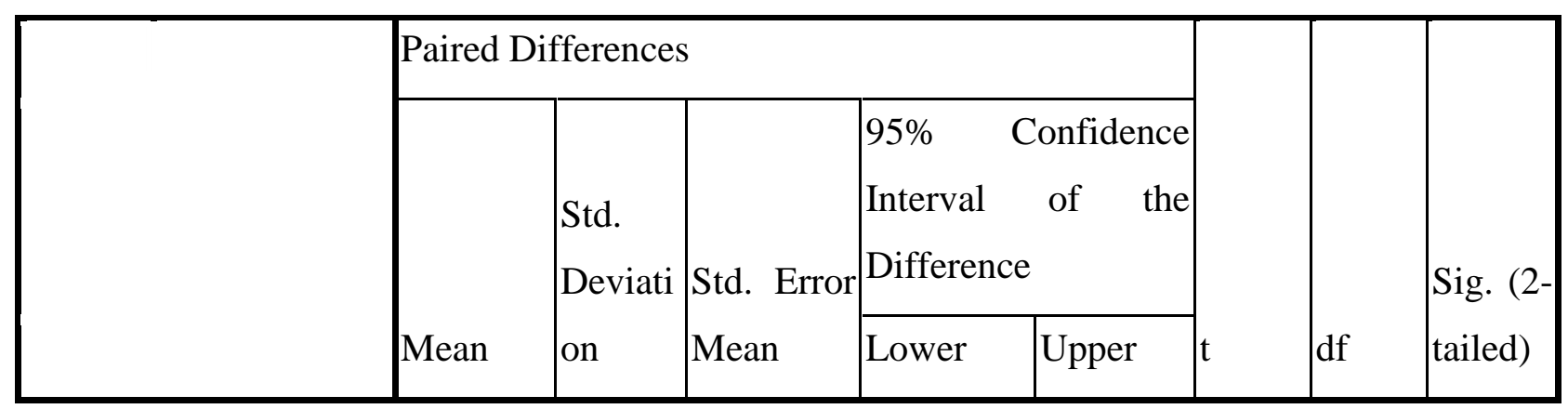

Script Journal Volume 1, Issue 2, October 2016 || P-ISSN 2477-1880 || E-ISSN 2502-6623

http://jurnal.fkip-uwgm.ac.id/index.php/Script 


\begin{tabular}{|c|c|c|c|c|c|c|c|c|c|}
\hline & & \multicolumn{5}{|c|}{ Paired Differences } & \multirow[b]{3}{*}{$\mathrm{t}$} & \multirow[b]{3}{*}{ df } & \multirow{3}{*}{$\begin{array}{l}\text { Sig. (2 } \\
\text { tailed) }\end{array}$} \\
\hline & & \multirow[b]{2}{*}{ Mean } & \multirow{2}{*}{$\begin{array}{l}\text { Std. } \\
\text { Deviati } \\
\text { on }\end{array}$} & \multirow{2}{*}{$\begin{array}{l}\text { Std. Error } \\
\text { Mean }\end{array}$} & \multicolumn{2}{|c|}{$\begin{array}{l}95 \% \text { Confidence } \\
\text { Interval of the } \\
\text { Difference }\end{array}$} & & & \\
\hline & & & & & Lower & Upper & & & \\
\hline Pair 1 & $\begin{array}{l}\text { Experimental } \\
\text { Group } \\
\text { Control Group }\end{array}$ & 9.63300 & $\begin{array}{l}10.589 \\
13\end{array}$ & 2.36780 & 4.67714 & 14.58886 & 4.068 & 19 & .001 \\
\hline
\end{tabular}

Table. 3 Paired Samples Test

On the post-test, the mean score of the experimental group was 80.2 and the mean score of control group was 70.4. It can be seen from the table above that the $\mathrm{t}$ - computed 4.068 is higher than $t$ - table 2.093 or $4.068>2.093$ with the level of significant $5 \%$. The computation showed that the mean scores of the two groups significantly differed. In other words, teaching English vocabulary by using VCD Learning as the instructional media gave significantly better result.

\section{DISCUSSION}

As stated previously on the first chapter that the main aim of conducting this research was to know whether there was significant difference of vocabulary mastery between the students of kindergarten level in Smart and Fun Communicative English Program Samarinda who taught with and without using CVD Learning as the instructional media.

Based on the result of the study, it is seen that the test showed the average scores of pre-test and post-test of experimental and control group were different. This means that the technique used in teaching English vocabulary gave significant result to students' vocabulary acquisition.

The improvement of children with the vocabulary with VCD Learning can be seen from the result of the study. The result of mean computation score of experimental group score was higher than the mean score of control group. It means the students' vocabulary of the experimental group increased greater than the control group after treatment. In 
conclusion, there was a significant difference before and after treatment of experimental and control group.

This research has proved that using CVD Learning as the instructional media in teaching English vocabulary made the post-test result of the students in the experimental group better than those in the control group.

The findings strengthen the VCD Learning as the instructional media theory stated by Stempleski (1987) that using video material in a non-English Language Teaching (ELT) environment can motivate students. Besides, (Collins et al, 1997) states that "multimedia give the power to the learners to explore and manipulate the information, beside to construct their own knowledge base".

The previous research in the area of teaching English vocabulary by using VCD as the instructional media conducted by (Pangaribuan, 2008), - a student of Mulawarman University - in her research, "The Effect of Teaching Vocabulary by Using VCD to the Fourth Grade Students of SDN 013 Sungai Kunjang Samarinda in 2009/2010 Academic Year" analyzed whether using VCD enriched vocabulary of the students. In her research, it was concluded that using VCD in teaching English vocabulary gave better result than without using VCD.

This result confirm the theories stated by (Webster, 1972) that teaching aids are many varieties of devices and materials, which rely on the sense of sight to inform. Without technique and teaching aids which are appropriate to the students' level, the students may get bored and not interested in following the lesson and the result will not be satisfactory.

Based on the results of this research, the use of VCD Learning as the instructional media for teaching English vocabulary to the students in basic level brings good effect. The students enjoy the lesson and they are interested in learning English vocabulary. It is strongly guessed that watching VCD Learning was a so impressive process for the students that when they were given the post-test, they could easily remember the words they found during the treatment process. It proved by having more correct answers and getting better score.

\section{CONCLUSION}

Based on the result of the analysis in the previous chapter, the researcher comes to the conclusion as the following that:

a. The researcher concluded that the effect of teaching English Vocabulary using VCD Learning to the kindergarten level students of Smart and Fun English Course

Script Journal Volume 1, Issue 2, October 2016 || P-ISSN 2477-1880 || E-ISSN 2502-6623 http://jurnal.fkip-uwgm.ac.id/index.php/Script 
Samarinda, can be seen from the mean pre-test and the post- test score of experimental group. (62.7 For pre-test and 80.1 for the post-test)

b. The researcher concluded that the effect of teaching English Vocabulary without using VCD Learning to the kindergarten level students of Smart and Fun English Course Samarinda, can be seen from the mean pre-test and the post test score of control group. (64.1 For pre-test and 70.4 for the post-test).

c. After analyzing the two mean scores on the post-test (80.2 for experimental group and 70.4 for control group), the researcher found that the t-computed 4.068.is higher than t-table 2.093. It means that there was significant effect of English vocabulary achievement between the kindergarten level students in Smart and Fun English course Samarinda who were taught with and without VCD Learning.

Based on those results, it is indicated that the Alternative Hypothesis that has been formulated "there is a significant effect in students' vocabulary achievement who were taught with VCD Learning" is accepted.

\section{BIBLIOGRAPHY}

Brophy, J., \& Good, T. L. (1986). Teacher behaviour and student achievement. Handbook of Research on Teaching, 328-375.

Collins, J. (1997). Teaching and Learning with Multimedia. London: Rotledge.

Creswell, J. W. (1994). Research Design Qualitative and Quantitative Approaches. London: Saga Publications.

Harmer, J. (2007). How to Teach English (An Introduction to the Practice of English Language Teaching. england: Longman.

Huyen, N. T. T., \& Nga, K. T. T. (2003). Learning Vovabulary Through Games: The Effectiveness of Learning Vocabulary Through Games, 5(4).

Pangaribuan, A. (2008). The Effect of Teaching English Vocabulary by Using VCD to The Fourth Grade Students of SDN 013 Sungai Kunjang Samarinda In 2008/2009 Academic Year. Mulawarman University.

Stempleski, S. (1987). Short Takes: Using Authentic Video in the English Class, (12-14 april), 17.

Webster, M. (1972). Webster's New World Dictionary of The American Language

Encyclopedic. the world publishing company.

Script Journal Volume 1, Issue 2, October 2016 || P-ISSN 2477-1880 || E-ISSN 2502-6623 http://jurnal.fkip-uwgm.ac.id/index.php/Script 
Yang, W., \& Fang, F. (2008). Optimization of Multimedia English Teaching, 1(4). 